\title{
SEMANTIC VALIDATION OF NURSING RESULT FALLS PREVENTION BEHAVIOR
}

\author{
VALIDAÇÃO SEMÂNTICA DO RESULTADO DE ENFERMAGEM \\ COMPORTAMENTO DE PREVENÇÃO DE QUEDAS
}

\section{Lorena Cabral FELIPE ${ }^{1}$; Ana Paula Nunes de Lima FERNANDES ${ }^{2}$; Diana Paula de Souza Rego Pinto CARVALHO ${ }^{2}$; Fabiane Rocha BOTARELLI ${ }^{3}$; Jéssica Naiara de Medeiros ARAÚJO' ${ }^{4}$; Marcos Antonio FERREIRA JÚNIOR ${ }^{5}$; Allyne Fortes VITOR ${ }^{6}$}

1. Enfermeira, Graduada pela Universidade Federal do Rio Grande do Norte - UFRN, Natal, RN, Brasil; 2. Enfermeira, Mestre em Enfermagem, Discente de Doutorado do Programa de Pós-Graduação em Enfermagem - UFRN, Natal, RN, Brasil; 3. Enfermeira, Mestre em Enfermagem, Professora Assistente II, Departamento de Enfermagem - UFRN, Natal, RN, Brasil; Discente de doutorado do Programa de Pós-Graduação em Enfermagem - UFRN, Natal, RN, Brasil; 4. Enfermeira, Discente de Mestrado do Programa de PósGraduação em Enfermagem - UFRN, Natal, RN, Brasil; 5. Enfermeiro, Doutor em Saúde e Desenvolvimento da Região Centro-Oeste, Professor do Departamento de Enfermagem - UFRN, Natal, RN, Brasil; 5. Enfermeira, Doutora em Enfermagem, Professora do Departamento de Enfermagem - UFRN, Natal, RN, Brasil.

\begin{abstract}
Objective: to determining the intelligibility of the indicators, constitutive and operational definitions of nursing behavior result of fall prevention by nurses in hospital units. Method: methodological research in adaptation to the instructions Hoskins validation model (1989), in order to performing the analysis of the intelligibility of the indicators, constitutive and operational definitions of nursing results NOC behavior of fall prevention. The instrument was therefore subjected to a sieve of nurses in a public teaching hospital of the health of the city of Natal/RN at the discretion of intelligibility chosen Psychometrics. Results: all indicators achieved or exceeded the concordance index of 0,90 , except for one indicator, because the concordance was 0,58 and $p<0,05$ as a result of the binomial test. It means therefore that this indicator needs to be revised. The other indicators with $\mathrm{p}$ values $<0,05$ were obtained concordance index between 0,90 and above experts so we were admitted to the final version. Conclusions: it can be concluded that the indicators, the constitutive definitions and the definitions/ operational magnitudes for the result of nursing NOC falls prevention behavior obtained agreement rate statistically higher than 0,90 . Considered by the target population, therefore, great intelligibility, similar to that shown in the scientific literature and able to measure the construct behavior prevention of falls in the hospital. From this perspective this study semantically validated a Prevention of falls in order to support nurse, assistant in the development of effective preventive activities, based on an instrument of scientific evidence.
\end{abstract}

KEYWORDS: Nursing. Accidental Falls. Prevention. Validation Studies.

\section{INTRODUCTION}

The occurrence of falls and its prevention remain a major challenge in all hospital environments. American studies conducted in developed countries indicate a rate of 3-5 drops per 1000 beds/day, which is about one million hospitalizations per year (OLIVER; HEALEY; HAINES, 2010; CHEN et al., 2009). A report published by The National Health Interview Survey (NHIS) states that unintentional falls are the most common cause of non-fatal injuries in hospitalized patients in the hospital environment (CHEN et al., 2009). It is noteworthy also that, between 2004 and 2007, the fall event was among the four leading causes of injuries in hospital patients (CHEN et al., 2009). Notably, its impact on individual health is quite variable, ranging from physical damage, disability and psychological harm to the patient and the family (BOUSHON et al., 2012; OLIVER; HEALEY; HAINES, 2010). Consequent to these, there is also the rising cost of health care, expressed using a variety of specialized services, and mainly by the increase in hospitalizations and/or hospital stays (CORREA et al., 2012). Thus, the drops become, over the years, a growing public health problem that needs to be discussed and solved.

Fall prevention in hospitals has been an area of particular concern for nursing. It is true that this adverse event (AE) is, for the most part, preventable in the hospital setting (BRASIL, 2013b), which the surveillance is essential, the development of precautionary measures and in particular the assessment of the patient and his propensity to fall which can be performed by nurses. Thus, to support and substantiate the evaluation of nursing stands out nursing taxonomies, especially the classification Nursing Outcomes Classification (NOC), it presents results to be measured, among which the behavior of preventing falls, which compiles indicators focused on falls prevention. 
The use of the Nursing Outcomes Classification (NOC) to assessing the assistance began in the mid-60. Since then, the literature has contributed with results validated to assess the quality of nursing care, as well as the effect of interventions, and confirms the importance of its use in nursing practice (MOORHEAD et al., 2013).

In this perspective, the result of nursing fall prevention behaviors proposed measure and, therefore, consider and present success and possible adaptations of nursing interventions by the process of the specific care to the risk of falls (GARCIA; NÓBREGA; CARVALHO, 2009; MOORHEAD et al., 2013; VITOR; ARAÚJO, 2011). Thus, the NOC defines the behavior of fall prevention as: actions of the individual or caregiver to minimize risk factors that can precipitate falls in the personal environment (MOORHEAD et al., 2013.). This result is presented in the NOC to contain:1. Name identifier; 2. Definition; 3. Set of indicators that serves as an aid to measure the result; 4. Likert scale that quantifies in five points each indicator, the sum of which will feature the health status of the evaluated individual.

The literature shows that it is of imperative validation the assessment of instruments, especially those related to nursing taxonomies (COSTA, 2014; GARBIN et al., 2009; VITOR; ARAÚJO, 2011). Therefore, there is a need for thorough improvement of tools for assessment of risk of falls (VITOR; ARAÚJO, 2011) in order to provide the basis for a more accurate measurement, specifically in hospitals.

Concerning the validity of a result of nursing, this refers to the level to which it can measure and identify health indicators, health status of the patient, family or community from the clinical trial and nurses' knowledge in carrying out nursing actions (SEGANFREDO; ALMEIDA, 2011).

However, the instruments those are available to evaluating a result of nursing as scales provided by the NOC, present difficulties to the use, since in some cases using general indicators that may not match the responses of certain health conditions (COSTA, 2014). Moreover, only the result of the indicators may not be sufficient to assess the actual health conditions reliably, considering being scored as the perception of each examiner (VITOR, 2010).

A version of the nursing outcome behavior fall arrest was previously built and validated the contents according to Psychometrics Pasquali (VITOR, 2010). This review culminated in indicators with their respective constitutive and operational definitions directed to the general population, with aspects involving falls prevention behaviors related to admission to hospital. Consequent of this, the model recommends Pasquali semantic validation to confirm the intelligibility of the instrument by the target population (PASQUALI, 1997), which was considered for this investigation as nurses in hospital units.

Thus, this research aimed to determe the intelligibility of the indicators, constitutive and operational definitions of nursing behavior result of fall prevention by nurses in hospital units.

\section{MATERIAL AND METHODS}

The semantic analysis has as primary purpose verifying that all items are understandable to all members of the population to which the instrument is intended (PASQUALI, 1997). The instrument was therefore subjected to a sieve of nurses in a teaching hospital of the public health system in the city of Natal/RN at the discretion of intelligibility chosen Psychometrics. In this step were selected nurses according to the inclusion criteria: be described in the institution professionals' framework; work in the institution there is at least one year; be present in the clinical hospital sector of the institution. As a criterion for exclusion, it was defined: the nurse considers that does not have time for the full trial of the survey items.

To select the sample, was conducted in the nursing board hospital, lifting the monthly scale of nurses, by which, we obtained a total of 49 nurses from three different shifts, of which 19 were selected for convenience ie were present in these sectors at the time of collection and met the criteria for inclusion in the sample. The procedure was then the presentation of the researcher, the objectives of the investigation, and the reading of the Consent and Informed (IC).

To nurses who met the criteria and agreed to participate by signing the informed consent, the intelligibility evaluation instrument was delivered. At the time, it was made for each nurse an explanation of the concept of intelligibility, the visual presentation of the evaluation instrument, the version of the nursing results containing all items that would be filed and again highlighted its evaluator function for trial assembly (indicators; constitutive definitions, operational definitions, and the magnitude of the operational settings) for each of 20 items, according to intelligibility. At the time, were resolved the doubts as to whether the instrument and set the period of one day for the return of the questionnaire. Thus, 12 nurses returned 
the instrument duly filled in and signed term composed, therefore, the research sample, as recommended by Pasquali for this type of validation (PASQUALI, 1997).

The intelligibility of validation instrument consisted of 20 items, divided into sub-items:

1. Title of the indicator; 2. Constitutive definition and operational definition, relevant to each indicator; 3. Operational Magnitudes constructed for each level of the indicators under the scale format Likert five points; 4. A range of two points (-1 and +1 ), in which the target population (nurses) evaluated the relevance of the set described above, as to its intelligibility; 5. A space for comments, suggestions and justifications.

To organizing the data, the notes indicated by the participants for each of the evaluated sets were tabulated, and then made the sum of indicator and calculated the arithmetic mean. For descriptive and inferential statistical analysis, we used a statistical package, whereby, we used the binomial test to examine if there was a statistically significant difference between the calculated arithmetic mean and the agreement index set of $0,90(90 \%)$. When considering a significance level $(p)$ of 0,05 , to rejecting the null hypothesis; the difference between the calculated average and the established level of agreement would occur if $p<0,05$.
Finally, suggestions, comments and justifications were considered; and, together with the product evaluations and by consensus among researchers, there has been proposed a final version to the result of nursing in question.

It should be noted that this research was approved by the Research Ethics Committee, in the opinion embodied 121.028 and CAAE 07614812.6.0000.5537, and was performed according to the recommendations of Resolution $466 / 2012$ of the National Health Council (BRASIL, 2012).

\section{RESULTS}

The participants were mostly female $(75 \%)$ with an average of 32,25 years old and the average training time since the completion of graduation was 7,6 years.

Below, presents the concordance rates of the target population about the intelligibility of each evaluated together. To corroborate the suggestions and recommendations made by experts, we used the binomial test in order to assess the adherence of the sets of indicators in relation to psychometric criteria, and the data obtained are shown in Table 1.

Table 1. Index of concordance of nurses (target population) as to the intelligibility of the indicators and their components. Natal, RN, Brazil, 2014.

\begin{tabular}{lr}
\hline \multicolumn{1}{c}{ Indicators } & Intelligibility \\
\hline 1. Correctly uses auxiliary mechanisms for wandering & 1 \\
2. Requests for physical aid & $0,282^{*}$ \\
& 1 \\
3. Makes use of barriers to prevent falls during the stay in bed & $0,282^{*}$ \\
& 1 \\
4. Makes use of handrails as needed & $0,282^{*}$ \\
5. Keep the environment free from accumulation of objects and obstacles and liquids & 0,92 \\
on the floor & $0,659^{*}$ \\
6. Uses properly stool and ladder & 1 \\
7. Uses appropriate footwear to preventing falls & $0,282^{*}$ \\
& 0,92 \\
8. Adjusts the height of the toilet as needed & $0,000^{*}$ \\
9. Uses properly chairs & 1 \\
\end{tabular}




\section{Uses properly bed}

12. Uses, in the bathroom, security bars for palmrest

As it was established, all indicators obtained or exceeded the concordance index of 0,90 , except for the indicator to "used properly chairs", because the concordance was 0,58 and $p<0,05$ as a result of the binomial test. Therefore means that this indicator needs to be revised, since the target population could not clearly grasp this indicator, their definitions and magnitudes. The other indicators with $\mathrm{p}$ values $<0,05$ were obtained concordance index between 0,90 and above experts so we were admitted to the final version.

\section{DISCUSSION}

The review, construction and content validation of indicators, operational definitions and magnitudes of a result of nursing are recommended steps in order to guide the assessment of the effectiveness of recommended preventive action for the prevention of falls (VITOR, 2010). For this analysis of the intelligibility of the nursing outcome behavior of preventing falls, the selection of the sample of nurses occurred in order that represents the profile of the target population of interest.

It is known, however, the difficulty of defining criteria for inclusion in studies of semantic validation, because in addition there is no consensus in the literature as to the specific criteria, it is relatively recent studies. Therefore, it is recommended that a study of semantic validation with a numerically more extensive sample.

The following will be discussed each indicator and its set of definitions and magnitudes, considering its importance for the refinement of the evaluation tool behavior of fall prevention.

\section{Correctly uses auxiliary mechanisms for wandering}

The literature indicates that auxiliary devices, although offering support and security, can bring physical harm to its users when used inappropriately (BRASIL, 2013a; OLIVEIRA et al., 2011; SANTOS et al., 2012). For this fact, many traumatic situations occur daily. An evaluation study of pipelines for the prevention of falls in patients with stroke found that $78.5 \%$ of the sample does not correctly used his auxiliaries (OLIVEIRA et al., 2011), which is a worrying fact since neglects this precaution further increases the risk of falls and injuries. 


\section{Requests for physical aid}

As pointed study, this preventive health behavior is defined as the request for help in performing the tasks considered by itself ariscadas for the occurrence of falls (VITOR, 2010). Often it has been reported falls in the room or in the patient's bathroom, where requests for assistance for personal hygiene are common, dressing, walking, climbing stairs and transfer from bed to chair (OLIVEIRA et al., 2011). Between 80 falls reported in one study, $55 \%$ were of the bed falls and 38,8\% falls from height, occurring mainly at night, trying to move without the necessary help (PAIVA et al., 2010).

\section{Makes use of barriers to prevent falls during their stay in bed}

Often falls occur at the bedside when the patient is lying down or getting up from the bed, raising the concern of nurses on the use of restrictive side rails in certain situations. Study infers that the frequency drops becomes high as not to use the restrictive side railings (PAIVA et al., 2010). There are reports; however, unrestricted patient falls in the bed, especially when disoriented and/or using psychotropic drugs in an attempt to go over bars (GANZ et al., 2013; PAIVA et al., 2010; SANTOS et al., 2012.)

\section{Makes use of handrails as needed}

Associated with the imbalance by postural instability are the physical adaptations of the environment that, if used, may modify the risk of falls and, among these adaptations is the use of rail. In a study of self-awareness about falls there was found that among the risk factors most often cited as predisposing to falls were the lack and/or poor positioning of handrails for the environment (GAI et al., 2010). It is understood that these lugs are important and must be arranged in stairs, ramps or local unevenness of the ground. It is noticed that in these environments most falls occur by not using the same associated with instability of gait and the imbalance of the patient. Study has shown that rail use is an effective strategy based on scientific evidence, becoming thus a universal strategy for the prevention of falls (GANZ et al., 2013).

\section{Keep the environment free from accumulation of objects and obstacles and liquids on the floor}

Upon investigation of the literature it has noted that environmental risk factors disadvantages the balance of the patients and may lead to destabilization. Thus predispose accidents by falls environments with furniture and objects/rugs scattered on the floor, low light and slippery (GANZ et al., 2013; GAI et al., 2010; SANTOS et al., 2012). In order to reducing the occurrence of inhospital fall, it is encouraged the use of general measures for preventing falls of all patients, regardless of risk. These measures include the establishment and maintenance, by the team and the patient, a safe care environment, such as non-slip floors, furniture and appropriate lighting, corridors and barrier-free rooms, the use of appropriate clothing and footwear and the safe transfer of patients (BRASIL, 2013a).

\section{Uses properly stool and ladder}

This indicator defines as up and down slowly stools of bed or stairs, one step at a time, with concentration, supporting the whole foot on the step, without distracting to reach objects (VITOR, 2010). In a self-perception study on falls, it was found that $59.1 \%$ of the population suggested as a way to prevent falls pay attention to the activity performed and $36.4 \%$ suggested looking at the obstacles at the time of activity (GAI et al., 2010). Study establishes as a preventive measure for such activity proper adjustment of the height of the bed in order to maintain full support of the foot on the stool/ladder; keep the bed wheels locked during the activity; inform and encourage the patient of the need to go up/down one step at a time; and inform you and encourage you to keep the necessary attention during the action (GANZ et al., 2013).

\section{Uses appropriate footwear to prevent falls}

In order to prevent accidents from falls in hospitalized patients who roam with or without help, the team should be attentive to the use of appropriate footwear (BRASIL, 2013a). In this perspective the use of proper shoes in the hospital appears in order to increase stability and grip plant during operation and protect the foot from possible mechanical damage and irregularities in the walking surface. Study of the outpatient elderly pointed out that at the time of drop $71 \%$ of the sample made use of inappropriate footwear, especially the tomboy type, sandal and slipper (DISH, SANTOS; TREVISANI, 2012).

Another study found that at the time of the fall the most common type of footwear was used slippers $(22 \%)$, followed by shoes $(17 \%)$ and sandals $(8 \%)$. Most patients $(75 \%)$ wear footwear with missing fastener (63\%) and/or heels/soles too flexible (43\%) (SHERRINGTON; MENZ, 2003). It is understood that, specifically in the hospital, people seek to use shoes they consider comfortable, without, however, turn their attention to the safety item; based on that we highlight as appropriate 
footwear closed shoes with non-slip fixing and firm sole.

\section{Adjusts the height of the toilet as needed}

A randomized clinical trial communitybased pointed out that $17,3 \%$ of falls that resulted in some kind of injury occurred within the bathroom being common place to sit/stand the toilet (STEVENS; MAHONEY; EHRENREICH, 2014). In a self-perception study on falls was found that $63.3 \%$ of the sample showed irregularities in the height of the toilet, characterizing it as an extrinsic to factor for falls in the bathroom (GAI et al., 2010). From this perspective, studies include in their care plan encouragement and certification of toilet height adjustment as well as the use of grab bars in the bathroom (GANZ et al., 2013; STEVENS; MAHONEY; EHRENREICH, 2014).

\section{Properly use of chairs}

This indicator defines itself as the use of chairs and armchairs to just sitting; and chooses those with arms and facilitate the act of sitting and standing (VITOR; ARAÚJO, 2011). In a selfperception study on falls was found that $18.2 \%$ of the population suggested as a way to prevent falls the use of chairs and seats only for the act of sitting (GAI et al., 2010). Like other devices, armchairs and recliners have the function of serving to support the act of sitting and standing, and should be taken into account, especially in a hospital environment once health status, the effects of drug therapy and environmental factors make this patient more vulnerable to suffer a fall (GANZ et al., 2013; BRASIL, 2013a; SANTOS et al., 2012;. STEVENS; MAHONEY; EHRENREICH, 2014; VITOR; ARAÚJO, 2011; VITOR; LOPES; ARAÚJO, 2010)

\section{Properly use of the bed}

This indicator defines as the use of actions aimed at reducing the risk of falls when lying down, when changing position of the bed or when going to bed or get up (VITOR; ARAÚJO, 2011). Study establishes as a preventive measure proper adjustment of the bed height to lie down/ stand up; keep the wheels locked bed; check instabilities of bed and mattresses; inform the patient about the alarm system and keep it within reach; maintain, where possible, personal effects of continuous use within reach; maintain high bars; contain the patient (if needed for security) (GANZ et al., 2013). It is noteworthy that the fall prevention must be balanced with the need to mobilize patients. It may be tempting to keep you in bed to prevent falls, however the transfer and ambulation is necessary to avoid complications in the bed rest and to maintain muscle strength and cognitive this patient.

\section{Uses properly tapes floor rubber tub/shower boxing}

It has been reported that one of the most common places for the occurrence of falls in hospitals is the bathroom, especially in boxing (PAIVA et al., 2010; GAI et al., 2010). An evaluation study of pipelines for the prevention of falls in patients with stroke found that $100 \%$ of their sample had no rubber mat inside the boxing (OLIVEIRA et al., 2011). It is understood that this is a very conducive environment for falls, since they generally exhibit a slippery material floors, requiring therefore a non-slip instrument as security.

\section{Uses, in the bathroom, security bars for palmrest}

In a randomized clinical trial communitybased pointed out that $17,3 \%$ of falls that resulted in some kind of injury occurred inside the bathroom (STEVENS; MAHONEY; EHRENREICH, 2014). There are several factors that predispose to falls, of common irregularities in relation to the grab bars and/or its use (PAIVA et al., 2010; GAI et al., 2010). Installing grab bars inside the box and next to the toilet seat allows the patient greater support to carry out the activities and the consequent security inside the bathroom. In this perspective study includes in its care plan encouragement and certification of the correct use of grab bars in the bathroom (GANZ et al., 2013).

\section{Controls restlessness}

Often health professionals, to turn more specifically, meet the physical needs in detriment to the mental and emotional aspects. A descriptive study on the characterization of the falls found that $61,7 \%$ of the cases studied occurred in the first five days and this may be related to the beginning of new medications, lack of familiarity with the environment and anxiety about the new condition, which generates restlessness (PAIVA et al., 2010). The assessment, treatment and health education about the control of anxiety/restlessness should be continuous character, to ease the emotional reactions of hospitalization.

\section{Performs precautions when taking medications that increase the risk of falls}

An observational study about the risk of falls in patients with unstable angina has highlighted the relationship between commonly prescribed medications with side prone effects of fall. In this study, the anti-hypertensive medication risk factor 
was present in $80,7 \%$ of the sample with very strong statistical association $(\varphi=0,765, p=0,000)$ and use of ACE inhibitor medication in $68,4 \%$, with strong statistical association $(\varphi=0,551, p=0,000)$ (VITOR; LOPES; ARAÚJO, 2010). Thus, the cognitive risk associated with the use of anxiolytic effect and hypotensive drugs, and the effects of drug interactions may lead to an increase in the vulnerability of the patient to suffer a fall, making again, protection and prevention a function the nursing team (GANZ et al., 2013; BRASIL, 2013a; SANTOS et al., 2012; VITOR; LOPES; ARAÚJO, 2010).

\section{Use resources appropriately vision correction}

It is known that visual deficiency when associated with low light can predispose slips, trips and falls, as it is an important component of the balance (LORD, 2006). Observational study about the risk of falling in patients with unstable angina has highlighted moderate association $(\varphi=0,509, \mathrm{p}=$ $0,000)$ between the visual risk factor difficulty and the risk of falls. This commitment can hinder the perception of objects on the ground, space limitations, levels and surfaces, slippery floors and small steps (BRASIL, 2013a; VITOR; LOPES; ARAÚJO, 2010). In this perspective study includes in its certification care plan the correct use of vision brokers mechanisms (GANZ et al., 2013). It follows, therefore, that have reduced ability to detect the visual environment hazards appears to be more personal commitment associated with falls.

\section{Use security actions during transfer}

The falls are not related solely to risk factors related to the individual. Associated with the imbalance by postural instability are the physical adaptations of the environment that, if used, may modify the risk of falling. Notably falls chairs/beds are related to the equipment, improperly planned or inadequate transfer techniques, when the patient is sitting or standing (PAIVA et al., 2010). Often occur in an attempt to move without the help needed influenced by anxiety and lack of familiarity with the space (PAIVA et al., 2010). It is understood that most falls occur by the instability of increased march of non-use of aid/support slides (PRATO; SANTOS; TREVISANI, 2012; SANTOS et al., 2012). Therefore, patients should be aware of the need to use aid / devices that make their safe transfer (VITOR; ARAÚJO, 2011). To this end, shall request the help of the staff, the height adjustments between chairs and other seating as well as use of the arms of supporters.

\section{Correctly uses the alarm system}

Most inpatients falls occur in patient rooms and are related to walking from bed to chair or toilet without adequate assistance (GANZ et al., 2013; OLIVEIRA et al., 2011; PAIVA et al., 2010; SANTOS et al., 2012; STEVENS; MAHONEY; EHRENREICH, 2014). Between 80 falls reported in one study, $55 \%$ were of the bed falls and $38.8 \%$ falls from height, occurring mainly at night, trying to move without the necessary help (PAIVA et al., 2010). The alarm system can be a useful component in the hospital falls prevention program (VITOR; ARAÚJO, 2011), provided that the patient know and understand the request for help as a preventive behavior, using the alarm system as a tool facilitator to drive the team when help is needed.

\section{Manages urinary /intestinal urgency}

It is understood that the eliminations consist of an essential activity to life, since your goal is to eliminate the toxic products resulting from the body's metabolism. With the natural aging process there are structural and metabolic changes that result in a gradual reduction in bladder capacity and development of involuntary contractions, causing symptoms of bladder and bowel urgency (VIRTUOSO; MAZO; MENEZES, 2012). In the hospital this situation tends to become a fall risk factor (GANZ et al., 2013).

As pointed study the behavior of properly managing these emergencies is set to use strategy or personal assistance to minimize or securely administer the sudden departure of the place where it is to meet the urgent need to urinate or evacuate (VITOR; ARAÚJO, 2011). A descriptive study on the characterization of the falls found that in $61,3 \%$ of cases of fall from height, 16,1\% had genitourinary problems (urinary urgency) (PAIVA et al., 2010). Coupled to these factors, a study said that of all falls, $45,2 \%$ were related to the toilet, especially falls on the path of bed/chair to the bathroom (TZENG, 2010).

In this sense, the nursing staff should focus on promoting the safe transfer through practical and educational actions with the patient and family and encourage the management of urinary urgency (keep urinal within reach, use of diapers, a reduction in liquid oral intake before sleeping).

\section{Makes use of appropriate size clothes}

Studies have shown that large, long clothes, dropping or dragging on the ground are important factors extrinsic to fall (GANZ et al., 2013; RAMOS et al., 2011), since they can hook and/ or become a factor for tripping. In a self-perception 
study on falls was found that $45,5 \%$ of the sample used inappropriate clothing at the time of the survey (GAI et al., 2010), which is a worrying fact, because the neglect this precaution further increases the risk of falls. It is understood that the use of inappropriate clothing in the hospital environment becomes a major risk factor, since during walking and/or transfer from bed to chair can get caught in equipment and cause damage, both for the patient fall as the appliance's fall involved. In this study includes perspective in their care plan and the incentive to certify the application of adequate size clothes (GANZ et al., 2013).

\section{Correctly uses hearing correction features when needed}

American study highlights the relationship between hearing loss and the risk of falls by revealing that even with mild hearing loss, patients are up to three times the risk of difficulty in maintaining gait and balance. According to the researcher people with hearing difficulties have poor awareness of their environment in general, and that makes them more likely to trip and fall. In their study, 2,017 people between 40-69 years of age participated; who had their hearing tested. It was found that people with mild hearing loss $(25 \mathrm{~dB})$ were almost three times more likely to have a history of falling. It was found that for each additional $10 \mathrm{dBs}$ of hearing loss, there was an increase of 1.4 in the risk of falling (LIN; FERRUCCI, 2012). In this study perspective includes in its care plan to certify the proper use of hearing brokers mechanisms where possible (GANZ et al., 2013).

Finally, it is considered that health is modern characterized in a continuous, with behaviors related to the search of being-better, risk behaviors and death (GAI et al., 2010). In the dynamic of being-rather, are preventive health behaviors defined by Pender (2002) as: actions voluntarily performed by the individual in relation to a specific grievance in order to minimize the potential for perceived threat.

The perception of the effectiveness of preventive behavior depends on an initial assessment of the perceived benefits of the proposed behavior (in reducing susceptibility to or severity of the condition) and limitation of the evaluation (real or perceived) to initiation or continuation of a behavior by the individual.

And it is precisely in order to guide the assessment of the effectiveness of recommended preventive action to prevent falls that we review content, build and evaluate the content validity of the indicators and their respective constituent definitions, operational definitions and magnitudes for the result NOC Falls Prevention behavior.

The use of instruments is essential to enable the establishment of a common language between professionals from different areas. Thus, the customer regarding information should be clear, objective, frequent and complete, so that allow the monitoring, evaluation and (re-) overall planning and continuous care. In addition to being tools to evaluate responses to treatments, provide data comparisons over time and allow the understanding and study of the problems observed in the daily nursing (SILVA et al., 2012).

\section{CONCLUSIONS}

Falls are often a combination of risk factors, intrinsic, extrinsic, and of the level of a person's risk behavior. In order to reducing such incidents nurses should be able to perceive, judge and take action aimed at preventing fall incident.

From this perspective this study validated semantically a prevention tool of falls in order to support the assistant nurse in the development of effective preventive activities based on an instrument of scientific evidence.

We submitted 20 indicators validation of intelligibility by nurses, and we can conclude that the indicators, the constitutive definitions and the definitions/operational magnitudes for the result of nursing NOC Falls Prevention behavior obtained agreement rate statistically higher than 0.90 . Considered by the target population, therefore, great intelligibility, similar to that shown in the scientific literature and able to measure the construct behavior prevention of falls in the hospital.

We emphasize the possibility of contributing to the improvement of the NOC taxonomy and therefore nursing language. The proposition of this refinement of the result of nursing Falls Prevention behavior, could allow the execution of the phases of planning and implementation of nursing interventions in a targeted way to specifically indicate which preventive behavior is less than ideal, how much needs to evolve as well allowing a better selection of which action is the most appropriate for each case. We recommend the clinical validation of the instrument to see if there is a significant difference between using and not using the settings of each item of the NOC result now studied.

As a complement, we highlight some guidelines to be taken consciously by nurses and nursing staff as a way of preventing falls behavior, 
as follows: assess the situation and inform the patient/caregiver on the proper use of auxiliary mechanisms to walk, well as tailor it to use; include in the plan of care for the prevention of falls the patient and family bond with the team through health education and interpersonal communication, able to promote the immediate request for assistance; individually evaluate the clinical situations to limit the arbitrary use of totally restrictive side rails that can generate other risk factors; encourage the patient to use the handrail in order to provide a safe transfer; encourage the use of non-slip shoes or slippers every time the patient out of bed, and appropriately sized clothes; make sure that the path to the bathroom this clear, dry and free of objects to manage the patient; instruct you to rely only on stationary objects to help to establish itself and to use the handrail in the bathroom and hallway; while maintaining the use of glasses or hearing aids when necessary and important items at your fingertips.

\section{ACKNOWLEDGEMENTS}

This study was entirely funded by the Brazilian National Council for Scientific and Technological Development (CNPq) $\mathrm{n}^{\circ}$ 486042/2011-1.

\section{REFERENCES}

BOUSHON, B.; NIELSEN, G.; QUIGLEY, P.; RUTHERFORD, P.; TAYLOR, J.; SHANNON, D.; RITA, S. How-to Guide: Reducing Patient Injuries from Falls. Cambridge, MA: Institute for Healthcare Improvement, 2012. Disponível em:

<http://www.ihconline.org/UserDocs/Pages/HowtoGuideReducingPatientInjuriesfromFalls_copy.pdf>. Acesso em: 06 mar. 2014.

BRASIL. Conselho Nacional de Saúde. Diretrizes e normas regulamentadoras de pesquisas envolvendo seres humanos - Resolução 466. Brasília: Ministério da Saúde, 2012. Disponível em: <http://conselho.saude.gov.br/resolucoes/2012/Reso466.pdf>. Acesso em: 20 jan. 2014.

BRASIL. Ministério da Saúde/ Anvisa/ Fiocruz. Anexo 1- protocolo prevenção de quedas. Protocolo integrante do Programa Nacional de Segurança do Paciente. Brasília: Ministério da Saúde, 2013a. Disponível em: <http://www.saude.mt.gov.br/upload/controle-infeccoes/pasta12/protocolos_cp_n6_2013_prevencao.pdf>. Acesso em: 16 mar. 2014.

BRASIL. Ministério da Saúde. Portaria no 529, de 01 de abril de 2013. Institui o Programa Nacional de Segurança do Paciente (PNSP). Brasília (DF): Ministério da Saúde; $2013 b$.

CHEN, L. H.; WARNER, M.; FINGERHUT, L.; MAKUC, D. Injury episodes and circumstances: National Health Interview Survey, 1997-2007. National Center for Health Statistics, v. 10, n. 241, p. 1-55, 2009. Disponível em: <www.cdc.gov/nchs/data/series/sr_10/sr10_241.pdf>. Acesso em: 06 mar. 2014.

CORREA, A. D.; MARQUES, I. A. B.; MARTINEZ, M. C.; SANTESSO, P. L.; LEÃO, E. R.; CHIMENTÃO, D. M. N. Implantação de um protocolo para gerenciamento de quedas em hospital: resultados de quatro anos de seguimento. Revista da Escola de Enfermagem da USP, v. 46, n. 1, p. 67-74, 2012. Disponível em: <http://www.scielo.br/pdf/reeusp/v46n1/v46n1a09.pdf>. Acesso em: 07 mar. 2014.

COSTA, A. G. S. Resultado de enfermagem comportamento de prevenção de quedas: validação de indicadores. 2014, 159 f. Tese (Doutorado)- Universidade Federal do Ceará, Fortaleza, 2014.

GAI, J.; GOMES, L.; NÓBREGA, O. T; RODRIGUES, M. P. Fatores associados a quedas em mulheres idosas residentes na comunidade. Revista da Associação Médica Brasileira, v. 56, n. 3, p. 327-332, 2010. Disponível em: <http://www.scielo.br/scielo.php?script=sci_arttext\&pid=S0104-42302010000300019>. Acesso em: 14 mar.2014. 
GANZ, D. A.; HUANG, C.; SALIBA, D.; SHIER, V.; BERLOWITZ, D.; LUKAS, C. V.; PELCZARSKI, K.; SCHOELLES, K.; WALLACE, L. C.; NEUMANN, P. Preventing falls in hospitals: a toolkit for improving quality of care. Rockville, MD: Agency for Healthcare Research and Quality, 2013. Disponível em: <http://www.ahrq.gov/research/ltc/fallpxtoolkit/>. Acesso em: 17 mar. 2014.

GARBIN, L. M.; RODRIGUES, C. C.; ROSSI, L. A.; CARVALHO, E. C. Classificação de resultados de enfermagem (NOC): identificação da produção cientifica relacionada. Revista Gaúcha de Enfermagem, v. 30, n. 3, p. 508-515, 2009. Disponível em: <http://www.scielo.br/pdf/rgenf/v32n1/a22v32n1.pdf>. Acesso em: 15 mar. 2014.

GARCIA, T. R.; NÓBREGA, M. M. L. Processo de enfermagem: da teoria à prática assistencial e de pesquisa. Escola Anna Nery Revista de Enfermagem, v. 13, n. 1, 2009. Disponível em: <http://www.eean.ufrj.br/revista_enf/20091/ARTIGO\%2024.pdf >. Acesso em: 15 mar. 2014.

HOSKINS, L. M. Clinical validation, methodologies for nursing diagnoses research. In: CARROLLJOHNSON, R. (Ed.). Classification of nursing diagnoses: Proceedings of the eighth conference of North American Nursing Diagnosis Association. Philadelphia: JB Lippincott, 1989. p. 126-131.

LIN, F. R.; FERRUCCI, L. Hearing Loss and Falls Among Older Adults in the United States. Archives of Internal Medicine, v. 172, n. 4, p. 369-371, 2012. Disponível em:

<http://www.ncbi.nlm.nih.gov/pmc/articles/PMC3518403/pdf/nihms424140.pdf>. Acesso em: 16 mar. 2014.

LORD, S. R. Visual risk factors for falls in older people. Age Ageing, v.35, suppl.2, p.ii42-ii45, 2006.

Disponível em: <http://ageing.oxfordjournals.org/content/35/suppl_2/ii42.long>. Acesso em: 16 mar. 2014.

MOORHEAD, S.; JOHNSON, M.; MAAS, M.; SWANSON, E. Nursing outcomes classification (NOC). 5. ed. St. Louis, Missouri: Elsevier, 2013.

OLIVEIRA, A. R. S.; COSTA, A. G. S.; SOUSA, V. E. C.; MOREIRA, R. P.; ARAÚJO, T. L.; LOPES, M. V. O.; GALVAO, M. T. G. Condutas para prevenção de quedas de pacientes com acidente vascular encefálico. Revista enfermagem UERJ, Fortaleza, v. 19, n. 1, p. 107-113, 2011. Disponível em: <http://www.facenf.uerj.br/v19n1/v19n1a18.pdf>. Acesso em: 16 mar. 2014.

OLIVER, D.; HEALEY, F.; HAINES, T. P. Preventing falls and fall-related injuries in hospitals. Clinics in geriatric medicine, v. 26, n. 4, p.645-692, 2010. Disponível em: <http://www.sciencedirect.com/science/article/pii/S0749069010000534>. Acesso em: 07 mar. 2014.

PAIVA, M. C. M. S.; PAIVA, S. A. R.; BERTI, H.; CAMPANA, A. O. Caracterização das quedas de pacientes segundo notificação em boletins de eventos adversos. Revista da Escola de Enfermagem da USP, v. 44, n. 1, 2010. Disponível em:< http://www.scielo.br/pdf/reeusp/v44n1/a19v44n1.pdf >. Acesso em: 16 mar. 2014.

PASQUALI, L. Psicometria: teoria e aplicações. Brasília: Editora Universidade de Brasília, 1997. 289p.

PRATO, S. C. F.; SANTOS F. C.; TREVISANI, V. F. M. Pé doloroso do idoso associado à incapacidade funcional. Revista Dor, v. 13, n. 1, 2012. Disponível em: <http://www.scielo.br/pdf/rdor/v13n1/a04v13n1.pdf>. Acesso em: 16 mar. 2014.

RAMOS, C. V.; SANTOS, S. S. C.; BARLEM, E. L. D.; PELZER, M. T. Quedas em idosos de dois serviços de pronto atendimento do Rio Grande do Sul. Revista Eletrônica de Enfermagem, v. 13, n. 4. p. 703-713, 2012. Disponível em: $<$ http://www.fen.ufg.br/fen_revista/v13/n4/pdf/v13n4a15.pdf>. Acesso em: 16 mar. 2014. 
SANTOS, S. S. C.; SILVA, M. E.; PINHO, L. B.; GAUTÉRIO, D. P.; PELZER, M. T.; SILVEIRA, R. S. Risco de quedas em idosos: revisão integrativa pelo diagnostico da North American Nursing Diagnosis Association. Revista da Escola de Enfermagem da USP, v. 46, n. 5, p. 1227-1236, 2012. Disponível em: < http://www.scielo.br/pdf/reeusp/v46n5/27.pdf >. Acesso em: 16 mar. 2014.

SEGANFREDO, D. H; ALMEIDA, M. A. Validação de conteúdo de resultados de enfermagem, segundo a Classificação dos Resultados de Enfermagem (NOC) para pacientes clínicos, cirúrgicos e críticos. Revista Latino-Americana de Enfermagem, v. 19, n. 1, 2011. Disponível em: <http://www.revistas.usp.br/rlae/article/view/4286/5450>. Acesso em: 15 de mar. 2014.

SHERRINGTON, C.; MENZ, H. B. An evaluation of footwear worn at the time of fall-related hip fracture. Age Ageing, v. 32, n. 3, p. 310-314, 2003. Disponível em: $<$ http://ageing.oxfordjournals.org/content/32/3/310.full.pdf?origin=publication_detail $>$. Acesso em: 17 mar. 2014.

SILVA, L. G; JODAS, D. A.; BAGGIO, S. C.; VITURID, W.; MATSUDA, L. M. Prescrição de enfermagem e qualidade do cuidado: um estudo documental. Revista de Enfermagem da UFSM, v. 2, n. 1, p. 97-107, 2012. Disponível em: <http://periodicos.ufsm.br/reufsm/article/view/4546/3131 z. Acesso em: 17 mar. 2014.

STEVENS, J. A.; MAHONEY, J. E.; EHRENREICH, H. Circumstances and outcomes of falls among high risk community-dwelling older adults. Injury Epidemiology, v. 1, n. 5, 2014. Disponível em:

$<$ http://www.injepijournal.com/content/1/1/5>. Acesso em: 17 mar. 2014.

TZENG, H. M. Understanding the prevalence of inpatient falls associated with toileting in adult acute care settings. Journal of nursing care quality, v. 25, n. 1, p. 22-30. 2010. Disponivel em: $<$ http://journals.lww.com/jncqjournal/Fulltext/2010/01000/Understanding_the_Prevalence_of_Inpatient_Falls.5 .aspx >. Acesso em: 17 mar. 2014.

VIRTUOSO, J. F.; MAZO, G. Z.; MENEZES, E. C. Prevalência, tipologia e sintomas de gravidade da incontinência urinária em mulheres idosas segundo a prática de atividade física. Fisioterapia em Movimento, v. 25, n. 3, p. 571-582, 2012. Disponível em: <http://www.scielo.br/pdf/fm/v25n3/13.pdf>. Acesso em: 16 mar. 2014.

VITOR, A. F. Revisão do resultado de enfermagem comportamento de prevenção de quedas: analise de conceito e validação por especialistas. 2010, 424f. Tese (Doutorado)- Universidade Federal do Ceará, Fortaleza, 2010.

VITOR, A. F.; LOPES, M. V. O.; ARAÚJO, T. L. Diagnóstico de enfermagem risco de quedas em pacientes com angina instável. Revista RENE, Fortaleza, v. 11, n. 1, p. 105-113, 2010. Disponível em: <http://www.revistarene.ufc.br/vol11n1_html_site/a11v11n1.htm>. Acesso em: 10 mar. 2014.

VITOR, A. F.; ARAÚJO. T. L. Definições para o resultado de enfermagem comportamento de prevenção de quedas: uma revisão integrativa. Revista Eletrônica de Enfermagem, v. 13, n. 2, p. 3113-322, 2011. Disponível em: <http://dx.doi.org/10.5216/ree.v13i2.14052>. Acesso em: 10 mar. 2014. 